\title{
LIGHT RAILWAYS FOR TROPICAL AFRICA
}

Or the many urgent and difficult Imperial problems which press for solution at the present moment, one of the most important and by no means the least difficult is that of the development of the vast regions in Tropical Africa, for which various European Powers have within the last quarter of a century made themselves responsible. Any idea of the colonisation of these countries by the white races is precluded, except in certain rare instances, by the climate, and in the majority a dense native population already exists, and is far more likely to increase than to diminish. These areas constitute, in fact, great trusts, and the problem before the white races is how best to administer them for the benefit of the inhabitants, and develop their resources so that they may take their place in the world's great markets. The problem will be seen to resolve itself into two main issues : first, the creation of a sound, strong, econumical and efficient administration which will ensure peace, freedom for individual effort, and justice for all; and secondly, the raising either by direct or indirect means, or by a combination of the two, of a revenue sufficient to support the administration, and to carry out such public works as are necessary for the welfare of the country.

The creation of a sound administration depends so much on the extent to which funds are available that it is necessary first to form some clear idea as to what resources these countries possess, and then to determine what is the best means for developing them.

Until recent years the white races confined their attentions almost entirely to the coast line. Here they formed settlements and traded with the natives, bringing out by sea such merchandise as they found the natives willing to accept in 
exchange for produce required for European markens. This, consisting mainly of sylvan produce such as oils, rubber, timber, fibres, etc., was collected at the ports themselves, and put straight on shipboard, so that no question of interior transport arose. Directly, however, Europeans began to penetrate farther inland, the situation altered completely. So far as a country was traversed by rivers, communication with the interior along their courses was possible. But Tropical Africa knows neither roads nor wheels, and districts not traversed by rivers were almost completely cut off from the outside world. It followed that, so long as the intercourse betwcen Europeans and natives was limited to trading, the former confined themselves to the neighbourhood of the large navigable rivers whence they could convey their merchandise by water to the ocean, and made no attempt directly to develop the rest of the country. It was not long, however, before political rivalry between the European States forced their several Governments to enter upon an active policy with regard to the trading rights secured by their merchants, and this policy culminated in a series of agreements by which the States recognised each other's rights to various areas in Tropical Africa, and assumed the administration of these in the form of Protectorates, Colonies, or otherwise. Immediately the administration of the inland districts was assumed, the question of transport began to press, for it was impossible any longer to confine operations to the seaboard and riverine areas. The Governments responsible for the administration of the countries were obliged to occupy districts far removed from any waterway, if only to fulfil the primary object of keeping the peace, and communication became of the utmost importance. Human porterage along native tracks constituted practically the sole means of transport, and this, though slow, cumbersome, and terribly expensive and wasteful, was made to suffice for the first urgent needs of administration. There now arose, however, a further, and if possible more serious difficulty, namely, the raising of a revenue suffcient to defray the expenses of administration. The wealth of Tropical Africa consists almost entirely in its sylvan and agricultural produce, and the labour by which these are ob- 
tained; but without the means of conveying that produce out of the country to markets where it could be sold, it was valueless. The rivers tapped only a small portion of the whole area, and some means must be devised by which the remainder could be brought into direct communication with European markets. It is obvious therefore that the solution of both branches of the problem of Tropical African administration and development lies in the creation of arteries of communication whereby the whole area may be brought into direct touch with European administrators, and whereby the native may be enabled to exchange his produce for the manufactured and other commodities for which he is dependent on outside sources. In no other way can the African obtain a footing in the world's market, or the European find a fresh market for his manufactured goods. And in no other way can the revenue necessary for the administration of the new countries be obtained. The problem, then, narrows itself down to the consideration of the best means of opening up those countries removed from the seaboard which are untraversed by navigable rivers.

The example of the Romans in constructing the magnificent highways by which they connected their possessions in Europe cannot be profitably followed in Tropical Africa. Torrential rains periodically converting every tiny stream into a raging river make good, well-ballasted roads, with the permanent bridges required to keep them open in all weathers, very costly things. Moreover, tsetse-fly infested belts, fatal to horses and cattle, prohibit in most localities the employment of draught animals, and thus make the general use of animal transport impracticable, even were such roads constructed. Modern science has, however, devised an alternative in the shape of mechanical transport, which is clearly destined to solve the problems under consideration. A system of railway construction, combined with the utilisation and improvement to the utmost extent possible of existing waterways, will obviously provide the necessary outlet for the rich resources of the interior. Connecting links may later on be supplied, either in the form of light surface tramways, or of roads capable of carrying motor-driven lorries, 
but it is safe to say that railways will form the best foundation for developing the inland regions of Tropical Africa.

Railway construction is, however, an even more costly undertaking than road making, and needs a large initial capital expenditure; yet from the very nature of things it is evident that the necessary funds will not be at the disposal of the countries which such railways are intended to develop. Nor can private enterprise be counted on to come forward with large sums where no return can be expected for a large number of years. Obviously it is a case where the Government which has made itself responsible for the countries will be obliged either directly to provide the funds, or to assist indirectly in obtaining them. If therefore the conclusion is accepted that a scheme of railway construction is the best, and indeed the only means of developing newly acquired territories in Tropical Africa, both in the interests of the natives themselves, and of the protecting Powers who have made themselves responsible, it is worth while devoting a little attention to various considerations which immediately arise.

In the first place, the scheme of railway construction must obviously be the very least ambitious compatible with the object in view. The first consideration must in fact be economy, the next rapidity of construction; for the main object of the railway will be to aid the development of the country, and by so doing raise funds for its administration. It is impossible therefore to devote too much thought to every detail of the subject, so that the very utmost value may be extracted for every farthing of expenditure. Now the fundamental idea of the construction and working of a light railway is the elimination of every kind of expenditure which is not essential to its efficiency as a means of transport, and the reduction of all permanent way, works, plant, and appliances to their simplest and most inexpensive forms. Hence light railways fulfil the conditions of economy and rapidity in construction which, as has already been pointed out, are such essential features in the problem.

The question then arises how funds may best be raised for the construction of a system of light railways, and what agency should be employed to build them. In certain cases 
where military or strategical considerations involved extreme urgency, the Protecting Country has itself provided the funds requisite for the capital expenditure on construction, as, for instance, in the case of the Uganda Railway. In most cases, however, a Colony undertaking railway construction has itself provided funds, generally by means of a guaranteed loan, as, for instance, in Sierra Leone, Lagos, and Italian Erythraea; in exceptional cases, funds have been provided by private enterprise in return for land or other concessions, or subsidies. The latter is not a method which possesses many advantages, whilst it labours under several grave disadvantages : to give a contract to a company and guarantee a certain annual dividend is, as a rule, unwise, because the company is apt to rely too much on its safe guarantee, to the neglect of the work : moreover, if a profit is to be made by building a railway, it is best that the Government should secure it, rather than a company. Hence it may be taken for granted that the usual method of raising funds will be by means of a State-guaranteed loan.

After this question comes that of the agency to which the construction of the railway is to be entrusted. Either a company must be given a contract to build the line, or the line may be built departmentally by the administration of the country concerned. It is usually supposed that enterprises are better carried out by private companies or individuals than by a Government. Governments are said to be bad managers, slow and unbusinesslike, whereas tenders bind the contractors to fulfil certain conditions and terms, while the financier reserves to himself a strict control. But if the construction of a railway is handed over to the Public Works Department of the country concerned, great economies may be effected, because the whole staff and every Department of the Administration can be utilised in furthering the work, plant can be carried at low rates on Government steamers whenever and wherever room can be found for it, in short, the whole resources of the country may be made available at any moment to give assistance towards the work. Even the military forces can be utilised if corps be raised and trained for pioneer and railway work, as has been done in India and 
Egypt. Hitherto, it is true, it has been the almost invariable practice to hand the work over to contractors : in the case of the French Guinea Railway from Konakry to Kurussa, the undertaking was originally handed over to a Concession Company: the German Usambara line in East Africa, originally undertaken also by a Company, had to be continued by the Imperial Government. But it is at least possible that considerable economy could be effected by a system of Departmental construction, a specially qualified staff of railway experts forming part of the Public Works branch of the Administration. The railway now being constructed in the interior of Nigeria on these lines is likely to prove a record for cheapness and rapidity of construction, and the system may well be adopted elsewhere. In military expeditions, such as the reconquest of the Egyptian Soudan in 1897 , a somewhat similar system was employed, and found both efficient and economical.

The next question is where railways should be built so as to achieve the maximum result in developing the new areas. Where navigable waterways exist, it is obvious that railways are not at the outset required : money is far better expended in improving such waterways by the introduction of dredgers, 8rc. It is obviously unsound policy to build railways in still undeveloped countries to compete with water transport : their primary use is to connect fertile areas with the coast where water communication is non-existent, or to bring produce to water-ways, or link up the latter one with another. Examples of the former are to be found in Sierra Leone, Lagos, the French Ivory Coast, German Tugoland, and British East Africa : while of the latter, the French railway from Kayes to Bammako, and the Congo railway from Matadi to Leopoldville, may be cited as examples. Here it may be pointed out that no great length of railway can hope to be a paying concern in the early stages of development, since the freight charges would be too heavy over a long distance to allow of the bulky African produce being exported with any hope of profit. Take, for example, the case of palm kernels. A ton of palm kernels costs, let us say, $£_{7}$ Ios. at the place where it is produced : if it has to be carried a distance of 240 miles to a 
seaport, at a freight charge of, say, 2d. per ton-mile, an addition is made of $\ell_{2}$ : add $\ell_{1}$ Ios. for ocean freight, and a further sum of $\ell_{2}$ for expenses of unlading, warehousing, insurance, customs, taxes, \&c., and its total cost landed, say, at Liverpool, will be $£ 13$, which is about the market price at that port, leaving no profit whatever for the merchant. Roughly, then, a length of 240 miles may be taken as the limit at present over which it will pay to export produce by rail, unless freight charges are reduced below the rate of $2 \mathrm{~d}$. per ton-mile. Is it possible so to reduce rates? Take an existing example. The Sierra Leone Railway, which is 220 miles in length, was built on a capital of $\ell_{1}, 500,000,1$ borrowed at $3 \frac{1}{2}$ per cent. Its working expenses, allowing for depreciation, are roughly $\ell_{70,000}$ per annum. Interest on capital expenditure comes to $£ 52,500$ per annum, and a further I per cent., or $£ 15,000$ per annum, is to be diverted to a sinking fund towards paying off the loan. The total annual receipts, therefore, to render it a paying concern, should be $£ 137,000$. It has a aft. 6in. gauge, and allowing four trains per working day, each consisting of six trucks carrying 7 tons, this gives 168 tons hauled daily during 313 working days of the year, or a total of 52,584 tons per annum. To produce the requisite return, the rate to be charged works out at nearly $3 \mathrm{~d}$. per ton-mile, so that it would seem that, so far from a 2 d. rate being reduced, it would have to be actually augmented if the railway is to pay its way. As a matter of fact, the minimum rate charged on the Sierra Leone Government Railway is 2.63 pence per ton-mile, the other rates being approximately $3 \mathrm{kd}$., $6 \mathrm{~d}$., and $9 \mathrm{~d}$. per ton-mile, according to the classification of goods carried. It is questionable, however, if it is not profitable to work a railway even at a loss in order to gain the immense benefits which arise from enabling the native to export his produce, and thus to develop the resources of the country. Rates fixed so as to balance the working expenses and interest on capital cost of a railway may be too high to obtain traffic-indeed, will

1 We think that the anthor ts alightly to error as to this. The total of the loan to which he refens was onty about $\ell_{1}, 300,000$, and large sams were expeoded oot of it on materworke, barracke, etc- $-\mathrm{ED}$. 
almost certainly be so at the outset. The German Usambara Railway makes a charge of as much as 43 pfennigs per tonkilometre, or nearly gd. per mile. The French General Railway, on the other hand, charges 8 centimes per ton-kilometre, or about Ifd. per mile. The Uganda Railway, which charges an even lower rate, has already begun to pay its working expenses. We see now the vital importance of the point already insisted on, namely, the need of economy in construction : to this may be added the avoidance of steep gradients, for it is impossible to keep working expenses down, and rates in consequence cheap, unless the gradients throughout are reasonably low.

The next point to consider is what is the most suitable gauge for a railway constructed with the object of developing a new country in Tropical Africa. The maximum gauge so far employed has been $3 \mathrm{ft}$. 6in., the minimum, $2 \mathrm{ft}$. The former is the gauge of most of the English railways-in the Gold Coast, Nigeria, and British Central Africa, for instance; of the Portuguese railways in Angola and Portuguese East Africa ; and of the German Dar es Salam-Mrogoro Railway. The French railways and the Uganda Railway are of metre gauge. The Sierra Leone Railway, the Congo Railway, and the German railways in Togoland and East Africa have a gauge of $2 \mathrm{ft} .6 \mathrm{in}$. The short German line in the Cameroons from Victoria is of $2 \mathrm{ft}$. gauge, as was originally the line now being widened in their South-West African Colony. Many experts consider the $2 \mathrm{ft}$. 6in. gauge as the most suitable for development purposes in Tropical Africa. An English writer considers the $2 \mathrm{ft}$. 6in. as "the ideal railway of heavy traffic capacity, shown by experience to possess the highest traffic capacity per cent. of cost of track." 1 M. Thys, the promoter of the Congo Railway, is reported as saying, "The gauge must be the narrowest, the construction the cheapest possible; the rails must be strong, the permanent way heavy, but the coaches light; in short, a good solid rail path following the gradient of the country, and not a real railway." 2 The principal savings in capital cost attained by narrowness of gauge

2 Piomaer Imigrtion and Light Raitrogs. By Mewron and Calthrop.

- Dis Eisonbakmon im tropischen Afrika. By Prof. Mejer. 
are due to the much greater flexibility of its alignment, since curves of a much smaller radius can, if necessary, be employed than on a railway of broader gauge. A narrow gauge railway can follow the contours of the country, and thus avoid deep cuttings and heavy embankments. It has been urged that so narrow a gauge has not the traffic capacity for the bulky goods which are exported from Tropical Africa, more especially for the raw cotton which it is hoped will be in future one of the main exports from our Tropical possessions, but it is not generally realised what exceedingly heavy loads can be transported by a railway with efficiently designed rolling stock of heavy traffic capacity. By designing locomotives so that their weight is distributed over a large number of axles, it is possible to make them of great haulage capacity, and yet without undue axle pressure. It is asserted that the Barsi Light Railway in India, of $2 \mathrm{ft}$. 6in. gauge, a single line with gradients of $I$ in 30 , combined with reversed curves of 300 feet radius, is capable of carrying no less than 946,080 passengers and 604,584 tons of goods per annum, and that even this is not the limit of its carrying capacity; for in a light railway, as traffic develops, the crossing places can be multiplied till the line practically becomes a double line. When these figures are compared with those already mentioned for the Sierra Leone Railway, it will be apparent how enormously the traffic capacity of a light line can be expanded as the traffic itself increases. It is, however, generally considered nowadays that $2 \mathrm{ft}$. $6 \mathrm{in}$. is too narrow a gauge for Tropical African railways, and the lines now being built are usually of $3 \mathrm{ft}$. 6in. gauge, with light rails, carrying powerful locomotives. This, combined with low gradients, gives an enormous haulage capacity, and consequent cheap freight rates-the one really important consideration.

We come finally to the question of labour for construction. In many cases, notably in Uganda, the Congo, and the Gold Coast, labour has been imported, but this is a plan which, apart from its expense, entails many grave disadvantages. It is obviously just and politic to arrange that the money expended on the construction of a railway built to develop

1 Pionas Imigution and Light Raikacys. By Mnwron and Calthorp. 
a Tropical African country, should be expended so far as possible amongst the natives of the country itself. Moreover, a large influx of alien natives, even if merely temporary, is for many reasons undesirable. The difficulty is that in Tropical Africa, owing partly to the long existence of slavery and partly to other causes, no real labour market was in existence prior to the advent of Europeans. Hence it has happened that where, as in many of the French possessions, the construction of railways was handed over to Concession Companies, great difficulty was experienced in obtaining labour, and in most cases the administration was obliged to come to the assistance of the companies. This may be done in two ways : either the Government may engage the labourers, and place them at the disposal of the company at a fixed rate of wages : or it may undertake the original preparation of the line, employing native labourers under their own Chiefs, the company merely finding the money to pay the proper wages : the more technical and skilled part of the work, for which so many labourers are not required, can be satisfactorily accomplished by the company itself. This was the method employed by the French in Dahomey and the Ivory Caast, and they claim that it has worked well. It assumes, however, that the natives are really fit labourers, and that there is a sufficient supply of them to ensure that the country will not suffer, by the employment of thousands on the railway, from lack of cultivation of the soil and consequent shortage of food. It could not have been applied, for instance, in the lower Congo or German South-West Africa. In German Togoland, on the other hand, the railway company does not require any such assistance, there being plenty of labour. No one system can be advocated, because local conditions vary, and what is suitable for one district may be utterly unsuitable for another.

It has been said that, owing to the absence of a labour market in newly-acquired Tropical African countries, the Government usually finds itself obliged to step in and provide the local labour for railway construction. This is generally effected by means of legislation ad hoc, whereby the Government is empowered to call on Chiefs to provide labour at 
certain fixed wages. The great advantage of such a system is that it does not disintegrate the native social organisation, but maintains all that is best in it. Legislation of the kind has often been assailed by well-meaning persons on the grounds that it is a form of compulsion, repugnant to modern ideas of liberty : a moment's thought will, however, show that it is in reality no more so than compulsory education, and far less so than compulsory military service in Europe. The labour is recruited through the medium of the native Chiefs, and each labourer receives a fixed daily wage, paid over to him in the current coin of the realm. There is no question, therefore, of exploiting the native for the selfish ends of the capitalist. On the contrary, he takes his part in the creation and maintenance of public works which are for the good of the community at large and of himself in particular: and he is, moreover, encouraged to put by money and become a capitalist himself, thus laying the foundation of true commercial prosperity. The objection is sometimes raised that such labour is equivalent to a tax, the native's wages merely returning to the tax collector. The answer is that the whole of his wages do not return to the tax collector : a considerable portion remains in his possession, which, if he is thrifty, forms a slowly increasing capital out of which he satisfies his growing wants by means of trade. The foundation of capital must always be laid in the first instance through labour; if this labour be not at first voluntarily offered, it must be induced by legislation, and public works which are of direct benefit to the community can thus be carried rapidly to completion. Needs and desires, and the means of their satisfaction, arise with the capital thus earned, and in this way the productive powers of a tropical country may be so increased that it will be able to attain in a short space of time a free and independent economic position, and at the same time shake itself free from the institution of slavery, which has for so many centuries choked its progress. To this end, railways are one of the most powerful aids, not only through their universal connecting power, but through the distribution of wealth where the natives have assisted in their construction. When the latter have ben educated both to labour for a common 
purpose, and to save up capital through their employment on railway construction, an immense benefit will have been conferred, both on themselves and on their country. It is not too much to say, in fact, that railway construction by the natives of an undeveloped tropical country, may, under a sympathetic Administration, be turned into a practical education for the native in the two qualities so much needed by them-thrift and self-help. Gladstone said characteristically : "It is selfhelp which makes the man; and man-making is the aim which the Almighty has everywhere impressed upon creation." Man-making is certainly the aim to be kept before administration in Tropical Africa.

Railways thus constructed and maintained may fairly be said to be the leading factors in the commercial life of a Tropical African country. Even if at first they do not pay, or only pay their working expenses, while the Colony or Protectorate pays the interest on the capital expenditure, they are invaluable for their power of developing the resources of the country. They enable the native to place on the world's market the results of his agricultural labours, and the inexhaustible products of his forests, and to receive in exchange the manufactures and inventions of the rest of the world's community; and in this way they provide the means for obtaining a revenue necessary for the efficient administration and policing of his country.

C. W. OrR. 